\title{
Simultaneous Differential Pulse Voltammetric Determination of L-Dopa and Carbidopa in Pharmaceuticals Using a Carbon Paste Electrode Modified with Lead Dioxide Immobilized in a Polyester Resin
}

\author{
Hélio Corrêa de Melo, ${ }^{a}$ Ana Paula D. Seleghim, ${ }^{b}$ Wagner Luiz Polito, ${ }^{b}$ Orlando Fatibello-Filho ${ }^{* c}$ \\ and Iolanda C. Vieira ${ }^{d}$ \\ ${ }^{a}$ Departamento de Química, Universidade Federal de Ouro Preto, 35400-000 Ouro Preto-MG, Brazil \\ ${ }^{b}$ Instituto de Química de São Carlos, Universidade de São Paulo, 13566-590 São Carlos- SP, Brazil \\ ${ }^{c}$ Departamento de Química, Centro de Ciências Exatas e de Tecnologia, \\ Universidade Federal de São Carlos, CP 676, 13560-970 São Carlos-SP, Brazil \\ ${ }^{d}$ Departamento de Química, Universidade Federal de Santa Catarina, \\ 88040-970 Florianópolis-SC, Brazil
}

\begin{abstract}
Um eletrodo de pasta de carbono modificado com dióxido de chumbo imobilizado em uma resina de poliéster foi desenvolvido para a determinação voltamétrica de pulso diferencial simultânea de L-dopa e carbidopa em formulações farmacêuticas. As curvas analíticas foram lineares em uma faixa de concentração de $2,6 \times 10^{-4}$ a $1,2 \times 10^{-3} \mathrm{~mol} \mathrm{~L}^{-1}$ e de $3,2 \times 10^{-5}$ a 1,5 $\times 10^{-4} \mathrm{~mol} \mathrm{~L}^{-1}$ para L-dopa e carbidopa, respectivamente. Os limites de detecção foram $2,5 \times$ $10^{-5} \mathrm{~mol} \mathrm{~L}^{-1}$ e $3,7 \times 10^{-6} \mathrm{~mol} \mathrm{~L}^{-1}$ para L-dopa e carbidopa, respectivamente e as recuperações de L-dopa e carbidopa em duas amostras variaram de 98,1 a $103 \%$. Os desvios padrão relativos foram menores que 2,5\% para soluções $1,2 \times 10^{-4}$ e $1,2 \times 10^{-3} \mathrm{~mol} \mathrm{~L}^{-1}$ dessas catecolaminas e os resultados obtidos para L-dopa e carbidopa em formulações farmacêuticas usando o procedimento voltamétrico proposto estão em boa concordância com os valores rotulados ou com aqueles teores determinados empregando-se um procedimento enzimático a um nível de confiança de $95 \%$.
\end{abstract}

A carbon paste electrode modified with lead dioxide immobilized in a polyester resin has been developed for simultaneous differential pulse voltammetric determination of L-dopa and carbidopa in pharmaceutical formulations. The analytical curves were linear in the concentration ranges from $2.6 \times 10^{-4}$ to $1.2 \times 10^{-3} \mathrm{~mol} \mathrm{~L}^{-1}$ and from $3.2 \times 10^{-5}$ to $1.5 \times 10^{-4} \mathrm{~mol} \mathrm{~L}^{-1}$ for L-dopa and carbidopa, respectively. The detection limits were $2.5 \times 10^{-5} \mathrm{~mol} \mathrm{~L}^{-1}$ and $3.7 \times 10^{-6} \mathrm{~mol} \mathrm{~L}^{-1}$ for L-dopa and carbidopa, respectively and recoveries of L-dopa and carbidopa from two samples ranged from 98.1 to $103 \%$ of the added amount. The relative standard deviations were lower than $2.5 \%$ for $1.2 \times 10^{-4}$ and $1.2 \times 10^{-3} \mathrm{~mol} \mathrm{~L}^{-1}$ of these catecholamines solutions and the results obtained for L-dopa and carbidopa in pharmaceutical formulations using the proposed voltammetric procedure are in close agreement with the labeled values and/or those obtained using an enzymatic method at the $95 \%$ confidence level.

Keywords: L-dopa, carbidopa, differential pulse voltammetry (DPV), carbon paste electrode modified with lead dioxide

\section{Introduction}

L-dopa [(-)-3-(3,4-dihydroxyphenyl)-L-alanine] and carbidopa [(-)-L-2-(3,4-dihydroxybenzyl)-2-hydrazinopropionic acid] are catecholamines with an alkylamine

*e-mail: bello@dq.ufscar.br chain attached to a benzene ring bearing two hydroxyl groups. They are used in several pharmaceutical formulations on association or each one alone for neural disorders compensations related to Parkinson's syndrome. ${ }^{1}$ Recently, experimental evidences show this disease as a consequence of some causes disturbing the production of the neurotransmitter dopamine. L-dopa is 
the immediate precursor of dopamine in the brain tissues. Nevertheless, L-dopa prescript as an active pure substance is ineffective itself on Parkinson's disease, since, in extra cerebral tissues, L-dopa is metabolized to dopamine and then to other metabolites, by a decarboxylation process. So, only a small fraction of unreacted carboxilated species, from a certain dosage of L-dopa, is transported across the cerebral tissues to the central nervous system. When carbidopa is used as inhibitor for the decarboxylase activity, with the concomitant use of carbidopa and L-dopa in pharmaceutical products, then a stronger concentration of the active catecholamine, i.e. L-dopa results. ${ }^{2}$ Hence, the development of a method for the simultaneous determination of L-dopa and carbidopa is very important, since they are frequently found together in some pharmaceutical formulations.

Several methods have been proposed for the simultaneous determination of these catecholamine drugs in biological specimens and/or pharmaceutical formulations. The determination of catecholamines in biological fluids normally requires the use of trace analysis techniques, mainly chromatography with fluorimetric or electrochemical detection. ${ }^{3}$ On the other hand, catecholamines are present in relatively large amounts in pharmaceutical formulations and much effort has been devoted to the development of simple, rapid, accurate and precise analytical methods. Of those, the most employed methods include spectrophotometry, ${ }^{4-6}$ high performance liquid chromatography (HPLC) with electrochemical detection ${ }^{7-15}$ and capillary zone electrophoresis (CZE) with electrochemical detection. ${ }^{16-20}$ To the best of our knowledge, there is only one differential pulse voltammetry (DPV) procedure in the literature using a glassy carbon electrode for the determination of L-dopa and a glassy carbon electrode coated with Nafion film for the determination of carbidopa. $^{21}$

DPV has been demonstrated to be a useful technique for the determination of many molecules of biological importance. ${ }^{22}$ The high selectivity, sensitivity, accuracy, precision, simplicity and the possibility of analysis without tedious sample pre-treatment are the greatest advantage of this technique.

In this paper the development and the application of a novel carbon paste electrode modified with lead dioxide immobilized in polyester resin for simultaneous differential pulse voltammetric determination of L-dopa and carbidopa in pharmaceuticals were presented. Catecholamines can be oxidized on classical electrodes such as $\mathrm{C}, \mathrm{Pt}$ and $\mathrm{Au}$. However, phenols and/or cathecolamines can cause anode inactivation by oligomer deposition on such electrode surfaces. ${ }^{23-25}$ For this reason, lead dioxide was used to oxidize catecholamines in aqueous acid solution where the reaction is very fast. On the other hand, $\mathrm{PbO}_{2}$ has attracted considerable attention owing to its low price compared to noble metals, its chemical stability in corrosive media, and high value of the overpotential for oxygen evolution reaction. ${ }^{23}$ Also, this oxide had been used as electrode in batteries, wastewater treatment, ozone generation, electrosynthesis ${ }^{24}$ and in $\mathrm{pH}$ electrode ${ }^{26}$ with very good performance.

\section{Experimental}

\section{Apparatus}

Cyclic-voltammetric and differential pulse voltammetric studies were performed with an EG \& G-PAR, Model 273A Potentiostat/Galvanostat (Princeton, NJ, USA). This system was controlled by mean of an interface connected to a PC microcomputer 486 DX4-120MHZ and the software M270 EG \& G PAR.

All electrochemical experiments were carried out in a $20 \mathrm{~mL}$ thermostated glass cell at $25^{\circ} \mathrm{C}$. A three-electrode assembly incorporating carbon paste electrode modified with lead dioxide as working electrode, an $\mathrm{Ag} / \mathrm{AgCl}$ (sat. $\mathrm{NaCl}$ ) reference and platinum wire auxiliary electrodes were used in all measurements.

\section{Reagents and solutions}

All reagents were of analytical grade and all solutions were prepared with water from a Millipore (Bedford, MA, USA) Milli-Q system (model UV Plus Ultra-Low Organics Water).

L-dopa was purchased from BDH (Poole, Dorset, UK) and carbidopa was kindly provided by Prodome Chemical and Pharmaceutical (Campinas, SP, Brazil). Stock solutions $\left(1.0 \times 10^{-2} \mathrm{~mol} \mathrm{~L}^{-1}\right)$ were prepared daily in several supporting electrolytes $\left(0.2 \mathrm{~mol} \mathrm{\textrm {L } ^ { - 1 }}\right.$ phosphate buffer solutions at $\mathrm{pH}$ ranging from 2 to 7 , perchloric, sulfuric and phosphoric acids at concentrations varying from 0.05 to $0.5 \mathrm{~mol} \mathrm{~L}^{-1}$ ). Reference solutions from $2.0 \times 10^{-5}$ to 2.0 $\times 10^{-3} \mathrm{~mol} \mathrm{~L}^{-1}$ were prepared from the stock solutions of the supporting electrolytes.

Carbon paste electrodes were prepared using solid paraffin (Sigma) and graphite powder (grade \# 38) from Fisher.

L-dopa and carbidopa were determined in solid pharmaceuticals acquired in local drugstores such as Prolopa $^{\circledR}$ (Roche Chemical and Pharmaceutical Products 
of São Paulo, SP, Brazil) and Sinemet ${ }^{\circledR}$ (Prodome Chemical and Pharmaceutical Ltda, Campinas, SP, Brazil).

\section{Immobilization of $\mathrm{PbO}_{2}$}

The immobilization of lead dioxide on the polyester resin was similar to that reported by Pereira and FatibelloFilho. ${ }^{27} \mathrm{~A}$ mass of $10 \mathrm{~g}$ of polyester resin solution was transferred to a silicone rubber flask; then $10 \mathrm{~g}$ of $\mathrm{PbO}_{2}$ were added and after manual homogenization, $0.5 \mathrm{~mL}$ of methylethylketone (catalyst) were added and stirred until an increase of viscosity. After 3-4 h, a rigid solid was obtained, which was broken with a hammer and a coffee grinder was used to obtain small particles. The particle size was selected by passing them through known mesh sieves and particles equal and/or smaller than $100 \mu \mathrm{m}$ were selected for the modified carbon paste electrodes construction.

\section{Carbon paste electrodes preparation}

The carbon paste electrode (CPE) was prepared manually by melting $0.125 \mathrm{~g}$ of the hydrophobic diluent (solid paraffin) $(25 \% \mathrm{~m} / \mathrm{m})$ in a mortar thermostatically controlled in a water bath at temperature close to its melting point $\left(54-56{ }^{\circ} \mathrm{C}\right)$. Subsequently, $0.375 \mathrm{~g}$ of graphite powder $(75 \% \mathrm{~m} / \mathrm{m})$ were added and mixed for 15 min with a glass spatula to obtain a homogeneous paste.

For carbon paste electrode modified with lead dioxide (MCPE) the following mass percentage ratios $(\% \mathrm{~m} / \mathrm{m})$ : (a) $65 \%$ of graphite, $25 \%$ of diluent and $10 \%$ of $\mathrm{PbO}_{2}$ immobilized in polyester; $(b) 55 \%$ of graphite, $25 \%$ of diluent and $20 \%$ of $\mathrm{PbO}_{2}$ immobilized in polyester; $(c)$ $45 \%$ of graphite, $25 \%$ of diluent and $30 \%$ of $\mathrm{PbO}_{2}$ immobilized in polyester and $(d) 25 \%$ of graphite, $25 \%$ of diluent and $50 \%$ of $\mathrm{PbO}_{2}$ immobilized in polyester were employed.

For CPE and MCPE a portion of each paste (about $0.170 \mathrm{~g}$ ) was packed into the tip of a $1 \mathrm{~mL}$ insulin plastic syringe $(9 \mathrm{~cm}$ high and $0.3 \mathrm{~cm}$ internal diameter; geometrical area of $0.070 \mathrm{~cm}^{2}$ ) and a silver wire was inserted to obtain the external electric contact as describe elsewhere. ${ }^{28}$

\section{Procedure and determination of L-dopa and carbidopa in pharmaceuticals}

All measurements were made in a thermostated glass cell at $25.0 \pm 0.2{ }^{\circ} \mathrm{C}$ in several supporting electrolyte.

The contents of 12 solid tablets were ground to a fine powder using a mortar and pestle. An accurately weighed amount of the resulting powder of 25-100 mg was transferred to a $100 \mathrm{~mL}$ beaker containing the 25 $\mathrm{mL}$ of supporting electrolyte and submitted to an ultrasound bath for $10 \mathrm{~min}$. After this, the suspension was passed through a Whatman \# 1 filter paper and the filtered solution was collected in a $100 \mathrm{~mL}$ calibrated flask and the volume was made up with the same supporting electrolyte. Then, appropriate dilutions were made and voltammetric measurements were carried out at $25.0 \pm 0.2{ }^{\circ} \mathrm{C}$.

\section{Results and Discussion}

\section{Cyclic voltammetry studies}

Initially, the electrochemical behavior of L-dopa and carbidopa on the MCPE was investigated by cyclic voltammetry in the following supporting electrolyte (0.2 $\mathrm{mol} \mathrm{L}^{-1}$ phosphate buffer solutions at $\mathrm{pH}$ ranging from 2 to 7 , perchloric, sulfuric and phosphoric acids at concentrations varying from 0.05 to $0.5 \mathrm{~mol} \mathrm{~L}^{-1}$. In this study, the potential was scanning between -100 and $+1100 \mathrm{mV}$ at a scan rate of $50 \mathrm{mV} \mathrm{s}^{-1}$. Of those supporting electrolyte solutions investigated better cyclic voltammogram shapes and peak separations were obtained using $0.1 \mathrm{~mol} \mathrm{~L}^{-1}$ perchloric acid solution at MCPE containing $20 \% \mathrm{~m} / \mathrm{m} \mathrm{PbO}_{2}$ in the carbon paste. In this supporting electrolyte solution no peak was observed in this potential range studied as can be seen in Figure $1 \mathrm{~B}$ (a). After addition of L-dopa (Figure $1 \mathrm{~A}$; $5.0 \times 10^{-4} \mathrm{~mol} \mathrm{~L}^{-1} \mathrm{~L}$-dopa) or carbidopa to the blank (Figure $1 \mathrm{~B} ; 3.0 \times 10^{-4}$ carbidopa) the same anodic peaks for both of them were observed at a peak potential of $677 \mathrm{mV}$. In the case of carbidopa a second anodic peak was observed at a potential of $1050 \mathrm{mV}$. The peaks obtained at potentials $677 \mathrm{mV}$ could be attributed to the electrochemical reaction of the two hydroxyls of L-dopa and carbidopa. The cyclic voltammogram of L-dopa (Figure $1 \mathrm{~A}$ ) shows a profile that corresponds to an irreversible process with anodic and cathodic peak potentials at $677 \mathrm{mV}$ and $300 \mathrm{mV}$, respectively. The voltammogram obtained for carbidopa (Figure $1 \mathrm{~B}$ ) presented two irreversible oxidation waves with maximum currents registered at $677 \mathrm{mV}$ and $1050 \mathrm{mV}$ and a cathodic peak potential at $300 \mathrm{mV}$. This is an indicative of the presence of coupled chemical reactions as it was well discussed by Quintino et al. ${ }^{21}$ Zhang et al. ${ }^{17}$ attributes this second anodic peak to the oxidation of imine group of the carbidopa. Figure $1 \mathrm{C}$ presents the cyclic voltammogram obtained for $1.25 \times 10^{-3} \mathrm{~mol}$ $\mathrm{L}^{-1} \mathrm{~L}$-dopa and $1.25 \times 10^{-4} \mathrm{~mol} \mathrm{~L}^{-1}$ carbidopa in $0.1 \mathrm{~mol}$ 
$\mathrm{L}^{-1}$ perchloric acid solution using the MCPC with 20 $\% \mathrm{~m} / \mathrm{m} \mathrm{PbO}_{2}$. In this study different concentrations of L-dopa and carbidopa were utilized simulating those concentrations normally found in pharmaceutical formulations. As can be observed the same anodic and cathodic peaks were obtained, suggesting that the first anodic peak $(677 \mathrm{mV})$ can be used for the determination of both compounds (L-dopa + carbidopa) and the second one at a potential of $1050 \mathrm{mV}$ can be used for the determination of carbidopa. Figure 2 presents the cyclic voltammograms of $5.0 \times 10^{-4} \mathrm{~mol} \mathrm{~L}^{-1} \mathrm{~L}$-dopa in $0.1 \mathrm{~mol}$ $\mathrm{L}^{-1} \mathrm{HClO}_{4}$ solution obtained with $\mathrm{CPE}$ (cyclic voltam-
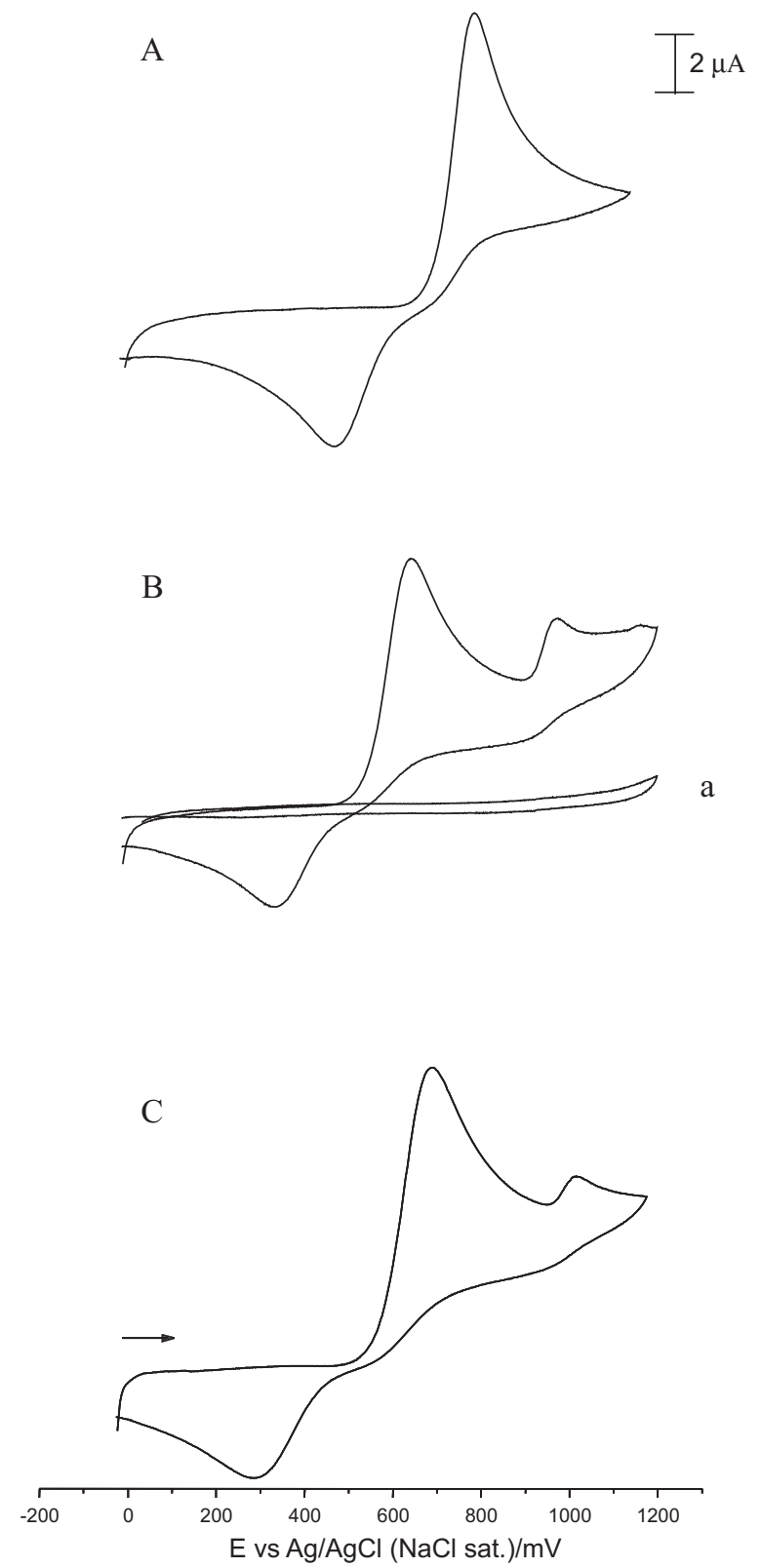

Figure 1. Cyclic voltammograms of (A) $5.0 \times 10^{-4} \mathrm{~mol} \mathrm{~L}^{-1} \mathrm{~L}$-Dopa, (B) $3.0 \times 10^{-4}$ carbidopa and (C) $1.25 \times 10^{-3} \mathrm{~mol} \mathrm{~L}^{-1} \mathrm{~L}$-dopa and $1.25 \times 10^{-4}$ mol L-1 carbidopa in $0.1 \mathrm{~mol} \mathrm{~L}^{-1} \mathrm{HClO}_{4}$ solution obtained using MCPE (b) with $20 \% \mathrm{~m} / \mathrm{m} \mathrm{PbO}_{2}$ at $25^{\circ} \mathrm{C}$ and $\mathrm{n}=50 \mathrm{mV} \mathrm{s}^{-1}$.

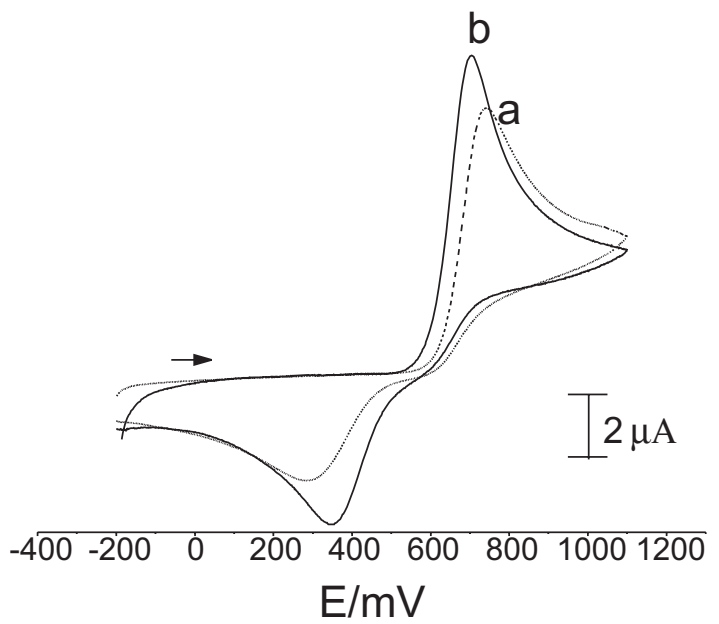

Figure 2. Cyclic voltammogram obtained for $5.0 \times 10^{-4} \mathrm{~mol} \mathrm{~L}^{-1} \mathrm{~L}$-dopa $0.1 \mathrm{~mol} \mathrm{~L}^{-1}$ perchloric acid solution using the CPE (cyclic voltammogram a) and MCPC with $20 \% \mathrm{~m} / \mathrm{m} \mathrm{PbO}_{2}$. (cyclic voltammogram b) at $25{ }^{\circ} \mathrm{C}$ and $\mathrm{n}=50 \mathrm{mV} \mathrm{s}^{-1}$.

mogram a) and MCPE electrode (cyclic voltammogram b). The cyclic voltammogram shape of L-dopa or carbidopa (not shown) obtained using the CPE was in accordance with that obtained by Zhang et al. ${ }^{17}$ using a carbon disk electrode and with that obtained by Quintino et al. ${ }^{21}$ using a glassy carbon electrode in the same supporting solution. Nevertheless, as can be seen from this figure, using the MCPE containing $20 \% \mathrm{~m} / \mathrm{m}$ $\mathrm{PbO}_{2}\left(10 \% \mathrm{~m} / \mathrm{m} \mathrm{PbO}_{2}+10 \% \mathrm{~m} / \mathrm{m}\right.$ polyester resin) there is an increase of peak current (anodic and/or cathodic). The decreasing of the potential peaks (anodic or cathodic) observed for the L-dopa or carbidopa (not shown) for MCPE suggesting that an electrocatalytic process is occurring and/or absence of adsorption of those compounds in the MCPE surface area.

\section{Electrode composition study}

The effect of the lead oxide varying from 0 to $50 \%$ $\mathrm{m} / \mathrm{m}$ and graphite powder from 75 to $25 \% \mathrm{~m} / \mathrm{m}$ at fixed amount of solid paraffin of $25 \% \mathrm{~m} / \mathrm{m}$ on the MCPE response for $1.0 \times 10^{-4} \mathrm{~mol} \mathrm{~L}^{-1} \mathrm{~L}$-dopa in $0.1 \mathrm{~mol} \mathrm{~L}^{-1}$ $\mathrm{HClO}_{4}$ was investigated. Figure 3 shows the dependence of peak potential (curve a) and peak current (curve b) as a function of the $\mathrm{PbO}_{2}$ content in the carbon paste using scan rate of $5.0 \mathrm{mV} \mathrm{s}^{-1}$, pulse amplitude of 50 $\mathrm{mV}$ and scan rate increment of $3 \mathrm{mV}$ at $25.0 \pm 0.2^{\circ} \mathrm{C}$. As it can be observed from this figure, the unmodified electrode (CPE; $0 \% / \mathrm{mm} \mathrm{PbO}_{2}$ ) presented a peak current of $6.0 \mu \mathrm{A}$ and a peak potential of $708 \mathrm{mV}$ and for a $20 \% \mathrm{~m} / \mathrm{m} \mathrm{PbO}_{2}$ composition a peak current of $12.1 \mu \mathrm{A}$ and a peak potential of $677 \mathrm{mV}$ were obtained. The results of lowered over-potential and increased current 


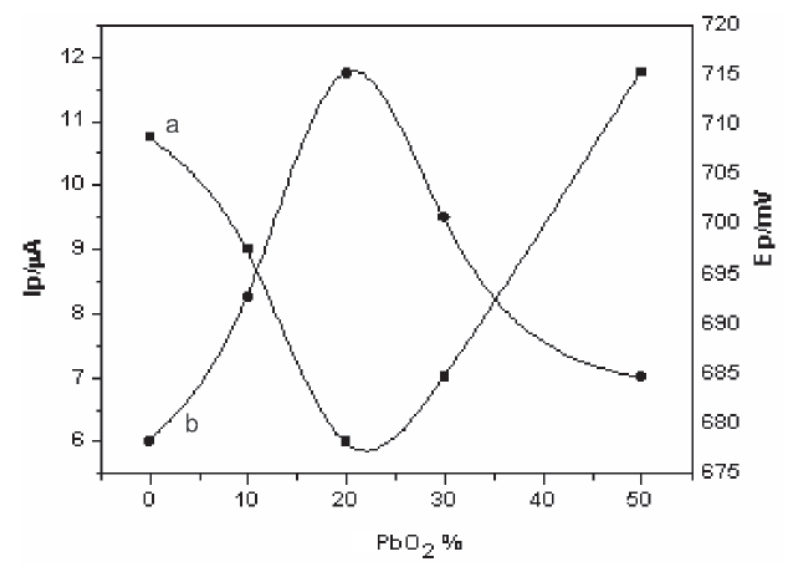

Figure 3. Dependence of peak potential (curve a) and peak current (curve b) as a function of the $\mathrm{PbO}_{2}$ content in the carbon paste at scan rate of 5.0 $\mathrm{mV} \mathrm{s}^{-1}$, pulse amplitude of $50 \mathrm{mV}$ and scan rate increment of $3 \mathrm{mV}$ and $25^{\circ} \mathrm{C}$.

response are clear evidence of the catalytic effect and/ or absence of adsorption of L-dopa. Similar results were obtained for carbidopa solution (results not shown). Therefore this electrode composition $\left(20 \% \mathrm{~m} / \mathrm{m} \mathrm{PbO}_{2}\right.$, $55 \% \mathrm{~m} / \mathrm{m}$ graphite powder and $25 \% \mathrm{~m} / \mathrm{m}$ solid paraffin) was selected for further studies.

\section{Differential pulse voltammetry study and analytical curves}

The differential pulse voltammetry (DPV) of $5.0 \times$ $10^{-4} \mathrm{~mol} \mathrm{~L}^{-1} \mathrm{~L}$-dopa and $8.0 \times 10^{-5} \mathrm{~mol} \mathrm{~L}^{-1}$ carbidopa solutions in $0.1 \mathrm{~mol} \mathrm{~L}^{-1} \mathrm{HClO}_{4}$ at $\Delta \mathrm{E}$ varying from 10 to $80 \mathrm{mV}$ were initially investigated. It has been noted that applied pulse amplitude has small influence on peak potentials. Nevertheless, the cathodic current peaks $\left(\mathrm{i}_{\mathrm{pc}}\right)$ obtained depend on of pulse amplitude applied to the working electrode (MCPE containing $20 \% \mathrm{~m} / \mathrm{m} \mathrm{PbO}_{2}$ ). It was found that the differential pulse voltammograms have better definitions using scan rate of $5.0 \mathrm{mVs}^{-1}$, pulse amplitude of $50 \mathrm{mV}$ and scan rate increment of $3 \mathrm{mV}$.

Under the optimum conditions established above, i.e. $0.1 \mathrm{~mol} \mathrm{~L}^{-1} \mathrm{HClO}_{4}$ as supporting electrolyte, scan rate of $5.0 \mathrm{mVs}^{-1}$, pulse amplitude of $50 \mathrm{mV}$ and scan rate increment of $3 \mathrm{mV}$, the differential pulse voltammograms from $2.6 \times 10^{-4}$ to $1.2 \times 10^{-3} \mathrm{~mol} \mathrm{~L}^{-1} \mathrm{~L}$-dopa and from 3.2 $\times 10^{-5}$ to $1.5 \times 10^{-4} \mathrm{~mol} \mathrm{~L}^{-1}$ were obtained and are shown in Figure 4 . The detection limits (three times the standard deviation of the base line/slope of the analytical curve) were $2.5 \times 10^{-5} \mathrm{~mol} \mathrm{~L}^{-1}$ and $3.7 \times 10^{-6} \mathrm{~mol} \mathrm{~L}^{-1}$ for L-dopa and carbidopa, respectively. The analytical curves obtained for L-dopa and carbidopa in those concentration ranges using the DPV technique, were $\mathrm{I}_{\mathrm{pa}}=0.4+8.0 \times 10^{4}$ [L-dopa] ( $\mathrm{r}=0.9998)$ and $\mathrm{I}_{\mathrm{pa}}=0.2+2.5 \times 10^{4}$ [carbidopa] $(r=0.9997)$, respectively where $I_{p a}$ is the anodic peak currents, in $\mu \mathrm{A}$ [L-dopa] and [carbidopa] is the L-dopa a

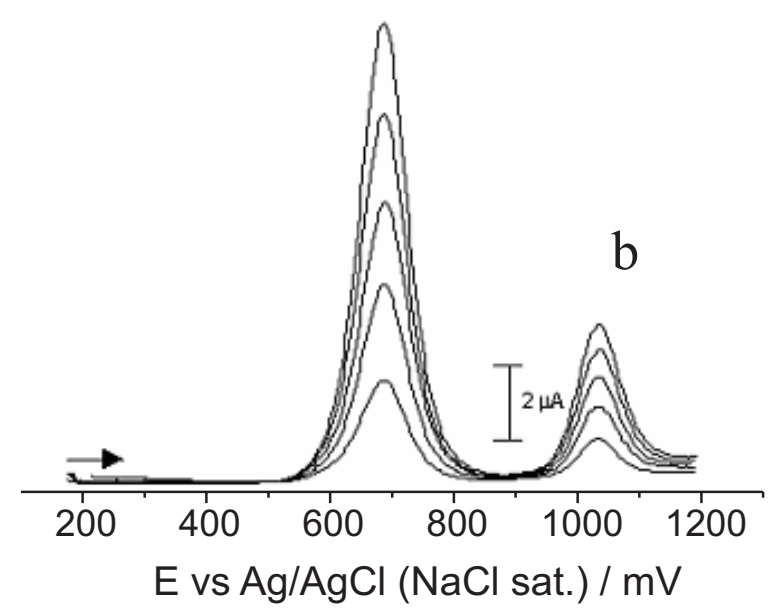

Figure 4. Differential pulse voltammograms obtained using the MCPE containing $20 \% \mathrm{~m} / \mathrm{m} \mathrm{PbO}_{2}$ for L-dopa (a) and carbidopa (b) solutions at concentration ranges from $2.6 \times 10^{-4}$ to $1.2 \times 10^{-3} \mathrm{~mol} \mathrm{~L}^{-1}$ and from $3.2 \times$ $10^{-5}$ to $1.5 \times 10^{-4} \mathrm{~mol} \mathrm{~L}^{-1}$ in $0.1 \mathrm{~mol} \mathrm{~L}^{-1}$ perchloric acid solution, respectively.

and carbidopa concentration, respectively in $\mathrm{mol} \mathrm{L}^{-1}$. Contrary to the conclusions of Zhang et al., ${ }^{17}$ owing to the similar electrochemical behavior of L-dopa and carbidopa at a carbon disk electrode and consequent difficulty to determine these analytes simultaneously by using conventional voltammetry. In another work, ${ }^{21}$ carbidopa could be analyzed in the presence of L-dopa, however, it was verified that L-dopa shows some interferences. Such a problem was solved after to coat the glassy carbon electrode with a Nafion film, which was selective to carbidopa. In the present work, using a $\mathrm{PbO}_{2}-$ modified electrode (MCPE) associated with differential pulse voltammetry technique, two well-defined peaks were obtained for L-dopa and carbidopa at potentials of 677 and $1050 \mathrm{mV}$, respectively, thus allowing the simultaneous determination of these catecholamines. The advantages of lead dioxide electrodes for high potential anodic processes as well discussed elsewere. ${ }^{23-25,30}$

Recovery, repeatability, interference studies and electrode lifetime

Recoveries varying from 98.1 to $104 \%$ of L-dopa and from 98.7 and 104\% of carbidopa from two pharmaceutical products were obtained using the modified electrode. In this study, 41.7, 80.3 and $116.2 \mu \mathrm{g} \mathrm{mL} \mathrm{m}^{-1}$ of L-dopa and 7.40, 14.8 and $22.3 \mu \mathrm{g} \mathrm{mL}^{-1}$ of carbidopa were added to the sample solutions $(n=6)$ and the differential pulse voltammograms were obtained (Table 1). The recovery results obtained for Sinemet and Prolopa samples suggest an absence of matrix effects in these determinations. 
Table 1. Results of addition-recovery experiments using L-dopa and carbidopa with three different standard concentrations

\begin{tabular}{|c|c|c|c|c|c|c|}
\hline \multirow[b]{2}{*}{ Sample } & \multicolumn{3}{|c|}{ L-dopa $/\left(\mu \mathrm{g} \mathrm{mL}^{-1}\right)$} & \multicolumn{3}{|c|}{ Carbidopa/ $\left(\mu \mathrm{g} \mathrm{mL} L^{-1}\right)$} \\
\hline & Added & Found & Recovery (\%) & Added & Found & Recovery (\%) \\
\hline \multirow{3}{*}{ Sinemet } & 41.7 & 42.1 & 101 & 7.40 & 7.30 & 98.7 \\
\hline & 80.3 & 82.8 & 103 & 14.8 & 14.7 & 99.3 \\
\hline & 116.2 & 117.2 & 101 & 22.3 & 22.8 & 102 \\
\hline \multirow{3}{*}{ Prolopa } & 41.7 & 43.3 & 104 & & & \\
\hline & 80.3 & 79.8 & 99.4 & & & \\
\hline & 116.2 & 114 & 98.1 & & & \\
\hline
\end{tabular}

${ }^{*} \mathrm{n}=6$, confidence level $95 \%$.

Table 2. Determination of L-dopa and carbidopa in pharmaceutical formulations using the enzymatic ${ }^{4}$ and differential pulse voltammetry procedures

\begin{tabular}{lcccccccc}
\hline & \multicolumn{2}{c}{ Label value / $(\mathrm{mg})$} & \multicolumn{2}{c}{ Enzymatic* $/(\mathrm{mg})$} & Differential pulse voltammetry* / (mg) & \multicolumn{2}{c}{ Relative error $(\mathrm{RE} \%)$} \\
\cline { 2 - 9 } Sample & L-dopa & Carbidopa & L-dopa & Carbidopa & L-dopa & Carbidopa & $\mathrm{RE}_{1}$ & $\mathrm{RE}_{2}$ \\
\hline Sinemet & 250 & 25 & $251.9 \pm 0.2$ & $25.2 \pm 0.1$ & $250.2 \pm 0.3$ & $25.6 \pm 0.1$ & -0.7 & 1.6 \\
Prolopa & 200 & 0 & $198.6 \pm 0.2$ & 0.0 & $199.8 \pm 0.8$ & 0.0 & 0.6 & 0.0 \\
\hline
\end{tabular}

${ }^{*} \mathrm{n}=6$, confidence level, 95\%. $\mathrm{RE}_{1}=$ Differential pulse voltammetry versus Enzymatic $(\mathrm{L}-\mathrm{dopa}) ; \mathrm{RE}_{2}=$ Differential pulse voltammetry versus Enzymatic (Carbidopa).

The relative standard deviations (RSDs) were 1.0 and $2.5 \%$ for solutions containing $1.2 \times 10^{-4} \mathrm{~mol} \mathrm{~L}^{-1}$ and $1.2 \times$ $10^{-3} \mathrm{~mol} \mathrm{~L}^{-1}$ of L-dopa and carbidopa $(\mathrm{n}=10)$, respectively.

The effect of excipient substances frequently found with L-dopa and carbidopa in pharmaceutical formulations, such as sucrose, glucose, fructose, lactose, starch, poly(ethylene glycol), sodium chloride, magnesium stearate and indigo carmine, was evaluated using the proposed procedure. The ratios of the concentrations of L-dopa or carbidopa to those of excipient substances were fixed at 0.1, 1.0 and 10.0. None of these substances interfered in the DPV method.

The lifetime of the electrode was at least 15 months (over 1,500 determinations were performed for the carbon paste amount ( $c a .0 .170 \mathrm{~g}$ ) used in the syringe), confirming the high stability of MCPE. By using $\mathrm{PbO}_{2}$ directly in the paste, the lifetime of the electrode was $c a$. 5-6 months (ca. 500 determinations).

\section{Application}

The DPV procedure at the experimental conditions presented above was applied to the determination of L-dopa and carbidopa in pharmaceutical products. Table 2 shows the results obtained for two commercial samples using an enzymatic method ${ }^{4}$ and the proposed MCPE. Applying a paired- $t$ test for the results obtained, it was found that all results are in agreement at the 95\% confidence level and within an acceptable range of error.

\section{Conclusions}

The studies described on this paper shows that L-dopa and carbidopa can be simultaneously determined in pharmaceuticals by differential pulse voltammetry using a carbon paste electrode chemically modified with $\mathrm{PbO}_{2}$ immobilized in polyester resin. Additional advantages like simplicity, rapidity to prepare and low cost can be also reach. Moreover, the good results obtained, such as reproducibility, precision, accuracy and longer lifetime of MCPE suggest the proposed method is suitable for determination of those catecholamines and it can be used in routine control analysis.

\section{Acknowledgments}

The authors wish to thank CNPq, FAPESP and CAPES for their financial support.

\section{References}

1. Coomes, M. W.; In Biochemistry with Clinical Correlations, Devlin, T. M. ed.; Willey: New York, 1997.

2. Pudek, M. R.; In Methods in Clinical Chemistry, Kaplan, L. A; Pesce, A.J. eds., Mosby: St. Louis, MO, 1996.

3. Moffat, A.C.; Clarke's Isolation and Identification of Drugs, Pharmaceutical Press: London, 1986.

4. Fatibello-Filho, O.; Vieira, I.C.; Analyst 1997, 122, 345.

5. Issopoulos, P.B.; Fresenius J. Anal. Chem. 1990, 336, 124.

6. Steup, A.; Metzner, J.; Voll, A.; Pharmazie 1986, 41, 739. 
7. Tolokan, A.; Klebovich, I.; BaloghNemes, K.; Horvai, G.; J. Chromatogr. B, 1997, 698, 201.

8. Kafil, J.B.; Dhingra, B.S.; J. Chromatogr. A 1994, 667, 175.

9. Rondelli, I.; Acerbi, D.; Mariotti, F.; Ventura, P.; J. Chromatogr. B 1994, 653, 17 .

10. Deleu, D.; Sarre, S.; Ebinger, G.; Michotte, Y.; J. Pharm. Biomed. Anal. 1993, 11, 577.

11. Miller, R.B.; Dehelean, L.;Belanger, L.; Chromatographia 1993, 35, 607 .

12. Wikberg, T.; J. Pharm. Biomed. Anal. 1991, 9, 167.

13. Lucarelli, C.; Betto, P.; Ricciarello, G.; Giambenedetti, M.; Corradini, C.; Stocchi, F.; Belliardo, F.; J. Chromatogr. A 1990, 511, 167.

14. Forster, I.; Junghanel, H.; Kropfgans, F.; Pharmazie 1998, 43, 47.

15. Michotte, Y.; Moors, M.; Deleu, D.; Herregodts, P.; Ebinger, G.; J. Pharm. Biomed. Anal. 1987, 5, 659.

16. Ha, P.T.T.; Van Schepdael, A.; Hauta-aho, T.; Roets, E.; Hoogmartens, J.; Electrophoresis 2002, 23, 3404.

17. Zhang, L.; Chen, G.; Hu, Q.; Fang, Y.Z.; Anal. Chim. Acta 2001, 431, 287.

18. Fanali, S.; Pucci, V.; Sabbioni, C.; Raggi, M.A.; Electrophoresis 2000, 21, 2432.

19. Sagar, K.A.; Smyth, M.R.; J. Pharm. Biomed. Anal. 2000, 22 , 613.
20. Wang, J.; Zhou, Y.; Liang, J.; He, P.G.; Fang, Y.Z., Chromatographia 2005, 61, 265.

21. Quintino, M.S.M.; Yamashita, M.; Angnes, L.; Electroanalysis, 2006, 18, 655 .

22. Fleet, B.; Fouzder, N.B. In Unit Processes In Organic Voltammetric Analysis - II. Determination; Franklin W. S.; ed., Academic Press: London, 1979.

23. Borrás, C.; Rodríguez, P.; Laredo, T.; Mostany, J.; Scharifker, B. R.; J. Appl. Electrochem. 2004, 34, 583.

24. Popovic, N. D.; Jonson, D.C.; Anal. Chem. 1998, 70, 468.

25. Rodgers, J.D.; Jedral, W.; Bunce, N. J.; Environ. Sci. Technol. 1999, 33, 1453.

26. Teixeira, M. F. S.; Ramos, L. A.; Fatibello-Filho, O.; Cavalheiro, E. T. G.; Fresinius J. Anal. Chem. 2001, 370, 383.

27. Pereira, A.V.; Fatibello-Filho, O.; Talanta 1998, 47, 11.

28. Vieira, I.C.; Fatibello-Filho, O.; Talanta 2000, 52, 681.

29. Brett, C.M.A.; Brett, A.M.O.; Electroanalysis, Oxford University Press: New York, 1998.

30. Amadelli, R.; Velichenko, A. B.; J. Serb. Chem. Soc. 2001, 66, 835.

Received: November 3, 2006

Web Release Date: July 11, 2007

FAPESP helped in meeting the publication costs of this article. 